\title{
Seasonal prevalence of different species of Culicoides in Bangalore rural and urban districts of South India
}

\author{
M. Archana ${ }^{1}$, Placid E. D'Souza ${ }^{1}$, C. Renuka Prasad ${ }^{2}$ and S. M. Byregowda ${ }^{3}$ \\ 1. Department of Veterinary Parasitology, Veterinary College, Karnataka Veterinary Animal and Fisheries \\ Sciences University, Hebbal, Bangalore -560024, Karnataka, India; 2. Vice Chancellor, Karnataka Veterinary Animal and \\ Fisheries Science University, Nandinagar, Bidar - 585401, Karnataka, India; 3. Institute of Animal Health \\ and Veterinary Biologicals, Hebbal, Bangalore - 560024, Karnataka, India \\ Corresponding author: M. Archana, email:archuvet610@gmail.com \\ PED: placid536@gmail.com, CRP: c.renukaprasad@gmail.com, SMB: byregowda@yahoo.com \\ Received: 15-04-2014, Revised: 12-06-2014, Accepted: 19-06-2014, Published online: 24-07-2014
}

doi: 10.14202/vetworld.2014.517-521 How to cite this article: Archana M, D'Souza PE, Renuka Prasad C and Byregowda SM (2014) Seasonal prevalence of different species of Culicoides in Bangalore rural and urban districts of South India, Veterinary World 7(7): 517-521.

\begin{abstract}
Aim: The study was undertaken to know the seasonal prevalence of different species of Culicoides in Bangalore rural and urban districts of South India.

Materials and Methods: The flies were collected with UV-light traps (Onderstepoort Veterinary Institute. ARC. LNR ??) during rainy season (south west monsoon: June, July, August and September: North West monsoon: October, November and December), winter season (January, February) and summer season (March, April and May) in eleven different farms of cattle, buffalo, sheep and goats in Bangalore rural and urban districts.

Results: From a total of 83, 629 number of Culicoides midges collected, $77906(93.16 \%)$ were female and 5723 (6.84\%) were males. In rainy season a total of 48,318 (57.77\%), winter season 18,592 (22.23\%) and summer season $16719(19.99 \%)$ were reported.
\end{abstract}

Conclusion: In rainy season, highest numbers of Culicoides were found whereas least in summer.

Keywords: biting midge, Culicoides, seasonal prevalence, South India.

\section{Introduction}

Culicoides is an important human and animal pest with great economic significance and a prime vector for various viruses like Bluetongue virus, African horse sickness virus, epizootic haemorrhagic disease, Akabane, Aino, Chuzan, and bovine ephemeral fever virus, Vesicular stomatitis virus, Equine Encephalitis Virus (EEV), Schmallenberg Virus, protozoa like Haemoproteus spp. and Leucocytozoon spp. and Hepatocystis, avian Trypanosomes, Plasmodium in lizard and bird malaria and filarid worms like Onchocerca cevicalis in horses. Dipetalonema spp., and Mansonella perstans and Mansonella ozzardi in humans and various filarid worms of birds, mammals [1].

Culicoides commonly known as biting midges is a nematocerous fly. It is one of the world's smallest haematophagous flies measuring from 1 to $3 \mathrm{~mm}$ in size. The family Ceratopogonidae to which it belongs contains 125 genera and 5,500 species. Of these genera, four are known to contain species that suck the blood of vertebrates viz. Austroconops, Culicoides, Forcipomyia (subgenus Lasiohelea), and Leptoconops. More than 1400 species of genus Culicoides have been identified worldwide of which about $96 \%$ are obligate blood feeders attacking mammals (including humans)

Copyright: The authors. This article is an open access article licensed under the terms of the Creative Commons Attribution License (http://creativecommons.org/licenses/by/2.0) which permits unrestricted use, distribution and reproduction in any medium, provided the work is properly cited. and birds and occur on virtually all large land masses with the exception of Antarctica and New Zealand, ranging from the tropics to the tundra and from sea level to $4000 \mathrm{~m}$ [2].

In India 63 species of Culicoides were identified morphologically and their prevalence reported by many authors from Kolkata [3, 4], Kolkata and the neighbouring areas [5], Assam and Bengal and parts of India [6], Chennai [7], Marathwada region of Maharashtra [8], Calcutta [9], Tamil Nadu [10, 11], Chittoor and Prakasam districts of Andhra Pradesh [12] and Northern Karnataka [13] region but there is a very scanty information on these midges in most parts of India including Karnataka. A detailed study was essential to know the prevalent species of Culicoides in Bangalore rural and urban districts.

In view of this scenario and lack of seasonal prevalence study in Karnataka, the present study was undertaken in Bangalore rural and urban districts.

\section{Materials and Methods}

The seasonal prevalence of Culicoides spp. was studied in eleven different farms of cattle, buffalo, sheep and goats in Bangalore rural and urban districts. The flies were collected with UV-light traps (Onderstepoort Veterinary Institute. ARC. LNR) during rainy season (southwest monsoon: June, July, August and September: North West monsoon: October, November and December), winter season (January, February) and 
Table-1: Morphometric measurements of Culicoides species

\begin{tabular}{|c|c|c|c|c|c|c|c|c|c|}
\hline Species & $\begin{array}{c}\text { Antenal } \\
\text { ratio }\end{array}$ & $\begin{array}{c}\text { Antenal } \\
\text { sensillar } \\
\text { pattern }\end{array}$ & $\begin{array}{l}\text { Palpal } \\
\text { ratio }\end{array}$ & $\mathrm{P} / \mathrm{H}$ ratio & $\begin{array}{l}\text { Wing length } \\
(\mathrm{mm})\end{array}$ & $\begin{array}{l}\text { Wing width } \\
(\mathrm{mm})\end{array}$ & Costal ratio & $\begin{array}{l}\text { Mandible } \\
\text { teeth }\end{array}$ & $\begin{array}{c}\text { Hindtibial } \\
\text { spine (largest } \\
\text { spine from } \\
\text { spur) } \\
\end{array}$ \\
\hline C. imicola & $\begin{array}{c}1.04 \\
(1.0-1.09)\end{array}$ & $3,12-15$ & $\begin{array}{c}2.4 \\
(2.1-2.6)\end{array}$ & 0.87 & $\begin{array}{c}0.93 \\
(0.8-0.99)\end{array}$ & $\begin{array}{c}0.45 \\
(0.42-0.5)\end{array}$ & $\begin{array}{c}0.54 \\
(0.5-0.57)\end{array}$ & 13 & $5(\mathrm{I})$ \\
\hline C. oxystoma & $\begin{array}{c}1.04 \\
(1.0-\mathrm{I} .13)\end{array}$ & $3,8-10$ & $\begin{array}{c}1.99 \\
(1.88-2.2)\end{array}$ & 0.66 & $\begin{array}{c}1.0 \\
(0.9-1.06)\end{array}$ & $\begin{array}{c}0.46 \\
(0.44-0.5)\end{array}$ & $\begin{array}{c}0.53 \\
(0.51-0.55)\end{array}$ & 12 & $4(\mathrm{I})$ \\
\hline C. peregrinus & $\begin{array}{c}1.18 \\
(1.12-3)\end{array}$ & $3, \| 1-15$ & $\begin{array}{c}2.9 \\
(2.5-3.44)\end{array}$ & 0.92 & $\begin{array}{c}1.19 \\
(1.06-1.26)\end{array}$ & $\begin{array}{c}0.54 \\
(0.45-0.57)\end{array}$ & $\begin{array}{c}0.64 \\
(0.62-0.67)\end{array}$ & 14 & $6(I I)$ \\
\hline C. actoni & $\begin{array}{c}1.1 \\
(1.06-15)\end{array}$ & $3,12-15$ & $\begin{array}{c}2.18 \\
(2.0-2.33)\end{array}$ & 0.73 & $\begin{array}{c}0.83 \\
(0.78-0.87)\end{array}$ & $\begin{array}{c}0.4 \\
(0.37-0.41)\end{array}$ & $\begin{array}{c}0.56 \\
(0.54-0.56)\end{array}$ & 13 & $5(I)$ \\
\hline C. huffi & $\begin{array}{c}1.36 \\
(1.3-1.46)\end{array}$ & $3,5,7-10$ & $\begin{array}{c}2.0 \\
(1.8-2.1)\end{array}$ & 0.58 & $\begin{array}{c}0.92 \\
(0.87-1.02)\end{array}$ & $\begin{array}{c}0.44 \\
(0.43-0.5)\end{array}$ & $\begin{array}{c}0.53 \\
(0.53-0.55)\end{array}$ & 10 & $4(\mathrm{I})$ \\
\hline C. innoxius & $\begin{array}{c}1.1 \\
(1.06-I .16)\end{array}$ & $3,11-15$ & $\begin{array}{c}2.76 \\
(2.5-3.0)\end{array}$ & 0.8 & $\begin{array}{c}1.18 \\
(1.1-1.28)\end{array}$ & $\begin{array}{c}0.53 \\
(0.48-0.57)\end{array}$ & $\begin{array}{c}0.68 \\
(0.66-0.68)\end{array}$ & 19 & $6(I I)$ \\
\hline C. anophelis & $\begin{array}{c}0.96 \\
(0.93-0.99)\end{array}$ & $3,11-15$ & $\begin{array}{c}2.2 \\
(2.2-2.3)\end{array}$ & 0.38 & $\begin{array}{c}1.1 \\
(1.07-1.12)\end{array}$ & $\begin{array}{c}0.54 \\
(0.45-0.57)\end{array}$ & $\begin{array}{c}0.71 \\
(0.69-0.72)\end{array}$ & 15 & $4(I I)$ \\
\hline C. palpifer & $\begin{array}{c}1.0 \\
(0.98--.07)\end{array}$ & $3,11-15$ & $\begin{array}{c}2.1 \\
(2-2.25)\end{array}$ & 0.56 & $\begin{array}{c}0.97 \\
(0.9-1.04)\end{array}$ & $\begin{array}{c}0.44 \\
(0.42-0.48)\end{array}$ & $\begin{array}{c}0.68 \\
(0.67-0.69)\end{array}$ & 7 & $4(I I)$ \\
\hline C. circumscriptus & $\begin{array}{c}1.12 \\
(1.1-I .16)\end{array}$ & $3-14$ & $\begin{array}{c}2.07 \\
(2.0-2.1)\end{array}$ & 0.91 & $\begin{array}{c}1.18 \\
(1.06-1.3)\end{array}$ & $\begin{array}{c}0.53 \\
(0.5-0.57)\end{array}$ & $\begin{array}{c}0.57 \\
(0.55-0.58)\end{array}$ & 15 & $4(1)$ \\
\hline C. arakawae & $\begin{array}{c}1.36 \\
(1.32-1.42)\end{array}$ & $3-14$ & $\begin{array}{c}2.4 \\
(2.33-2.6)\end{array}$ & 0.96 & $\begin{array}{c}1.12 \\
(1.03-1.23)\end{array}$ & $\begin{array}{c}0.5 \\
(0.43-0.54)\end{array}$ & $\begin{array}{c}0.6 \\
(0.58-0.62)\end{array}$ & 12 & $4(1)$ \\
\hline
\end{tabular}

Table-2: Season wise distribution of different species of Culicoides

\begin{tabular}{|c|c|c|c|c|c|c|c|c|}
\hline Species & Rainy & $\%$ & Winter & $\%$ & Summer & $\%$ & Total & $\%$ \\
\hline C. imicola & 19024 & $39.37 \%$ & 13820 & $74.33 \%$ & 7276 & $43.52 \%$ & 40120 & $47.97 \%$ \\
\hline C. oxystoma & 26613 & $55.08 \%$ & 4030 & $21.68 \%$ & 8723 & $52.17 \%$ & 39366 & $47.07 \%$ \\
\hline C. actoni & 1549 & $3.21 \%$ & 447 & $2.40 \%$ & 508 & $3.04 \%$ & 2504 & $2.99 \%$ \\
\hline C. peregrinus & 877 & $1.82 \%$ & 199 & $1.07 \%$ & 69 & $0.41 \%$ & 1145 & $1.37 \%$ \\
\hline C. huffi & 53 & $0.11 \%$ & 53 & $0.29 \%$ & 39 & $0.23 \%$ & 145 & $0.17 \%$ \\
\hline C. innoxius & 107 & $0.22 \%$ & 0 & 0 & 23 & $0.14 \%$ & 130 & $0.16 \%$ \\
\hline C. palpifer & 50 & $0.10 \%$ & 9 & $0.05 \%$ & 31 & $0.19 \%$ & 90 & $0.11 \%$ \\
\hline C. anopheles & 30 & $0.06 \%$ & 11 & $0.06 \%$ & 26 & $0.16 \%$ & 67 & $0.08 \%$ \\
\hline C. circumscriptus & 8 & $0.02 \%$ & 13 & $0.07 \%$ & 16 & $0.1 \%$ & 37 & $0.04 \%$ \\
\hline C. arakawae & 7 & $0.01 \%$ & 10 & $0.05 \%$ & 8 & $0.05 \%$ & 25 & $0.03 \%$ \\
\hline Total & 48318 & $57.77 \%$ & 18592 & $22.23 \%$ & 16719 & $19.99 \%$ & 83629 & \\
\hline
\end{tabular}

summer season (March, April and May). The insects were collected in the light traps, kept from $6 \mathrm{pm}$ to 6 am, and positioned within close proximity of $25 \mathrm{~m}$ where the livestock were kept at night at $1.5-2.0 \mathrm{~m}$ above the ground level and a glass collecting beaker containing $200-300 \mathrm{ml}$ of water (to which a drop of detergent was added to reduce surface tension) and was placed at the base of each trap. The collected insects were transported to the laboratory and preserved in $70 \%$ ethanol. Ceratopogonids were first separated from all other insects. Identification of Culicoides was initially based upon wing pattern and confirmed subsequently by mounting different parts of the specimen in drop of phenol-balsam mixture on microscope slides after clearing in liquefied phenol solution for $12 \mathrm{~h}$ [14].

Morphological identification of Culicoides spp. was done by using keys of [4, 9, 15-18]. The characters for morphological identification of Culicoides spp. included wing markings, presence and distribution of macrotrichia, lengths of flagellar segments 3-15, length of 5 palpal segments, antennal ratio \& palpal ratio, distribution of antennal coeloconica, form of sensory pit on $3^{\text {rd }}$ palpal segment, form of whole $3^{\text {rd }}$ palpal segment, proboscis-head ratio, number $\&$ form of spermathecae, form of male genitalia, appearance of leg \& thorax, number (sometime absence) of teeth of mandible, number of hind tibial comb and largest spine among them (i.e. on third pair of legs), length of body, length and breadth of wing, costal ratio.

\section{Results}

Morphologically a total of ten different species (Table-1, Fig:1-2 showing predominant Culicoides spp. C. imicola and C. oxystoma respectively) of Culicoides were found to be prevalent in eleven different farms viz. Culicoides imicola, C. oxystoma, $C$. peregrinus, C. actoni, C. anopheles, C. palpifer, $C$. huffi, C. innoxius, C. arakawae, and C. circumscriptus. During the different seasons a total of 83, 629 Culicoides midges were collected, out of these 77906 were female Culicoides (93.16\%) and 5723 were male Culicoides (6.84\%) from different farms of rural and urban districts of Bangalore. C. imicola and $C$. oxystoma were found to be the most predominant species found followed by C. actoni and C.peregrinus.

In rainy season a total of $48,318(57.77 \%)$, winter season, 18,592 (22.23\%) and summer season, 16719 (19.99\%) midges were collected (Table-2).

In rainy season, $C$. oxystoma was found to be the highest followed by $C$. imicola, C. actoni, $C$. peregrinus where as other species were found in less number. In winter, $C$. imicola was found to be highest followed by C. oxystoma, C. actoni and C. peregrinus. 

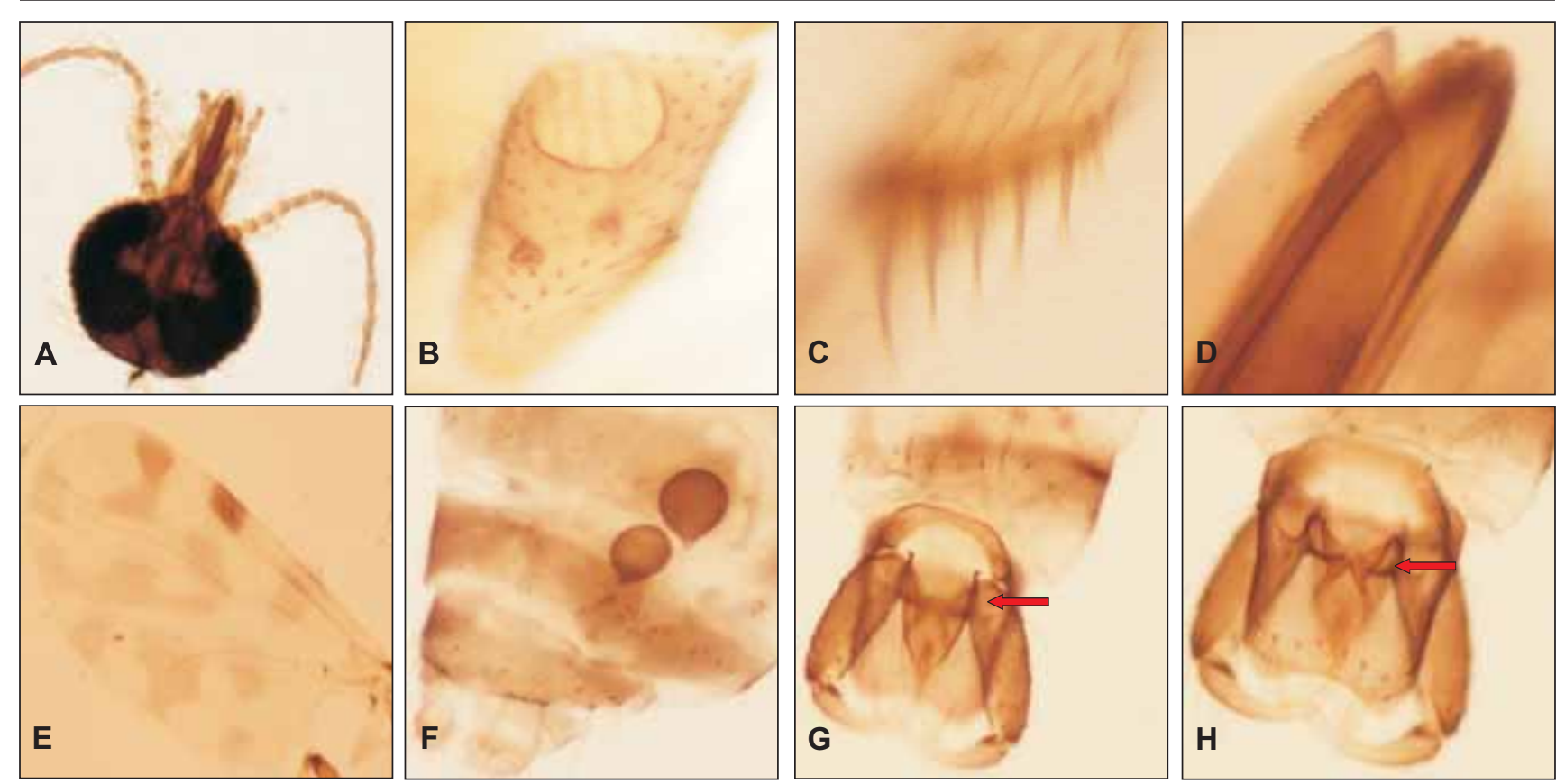

Figure-1: C. imicola - A. head, B. maxillary palp, C. hind tibial spine, D. mandibular teeth, E. wing, F. spermathecae, G-H. male genetalia.
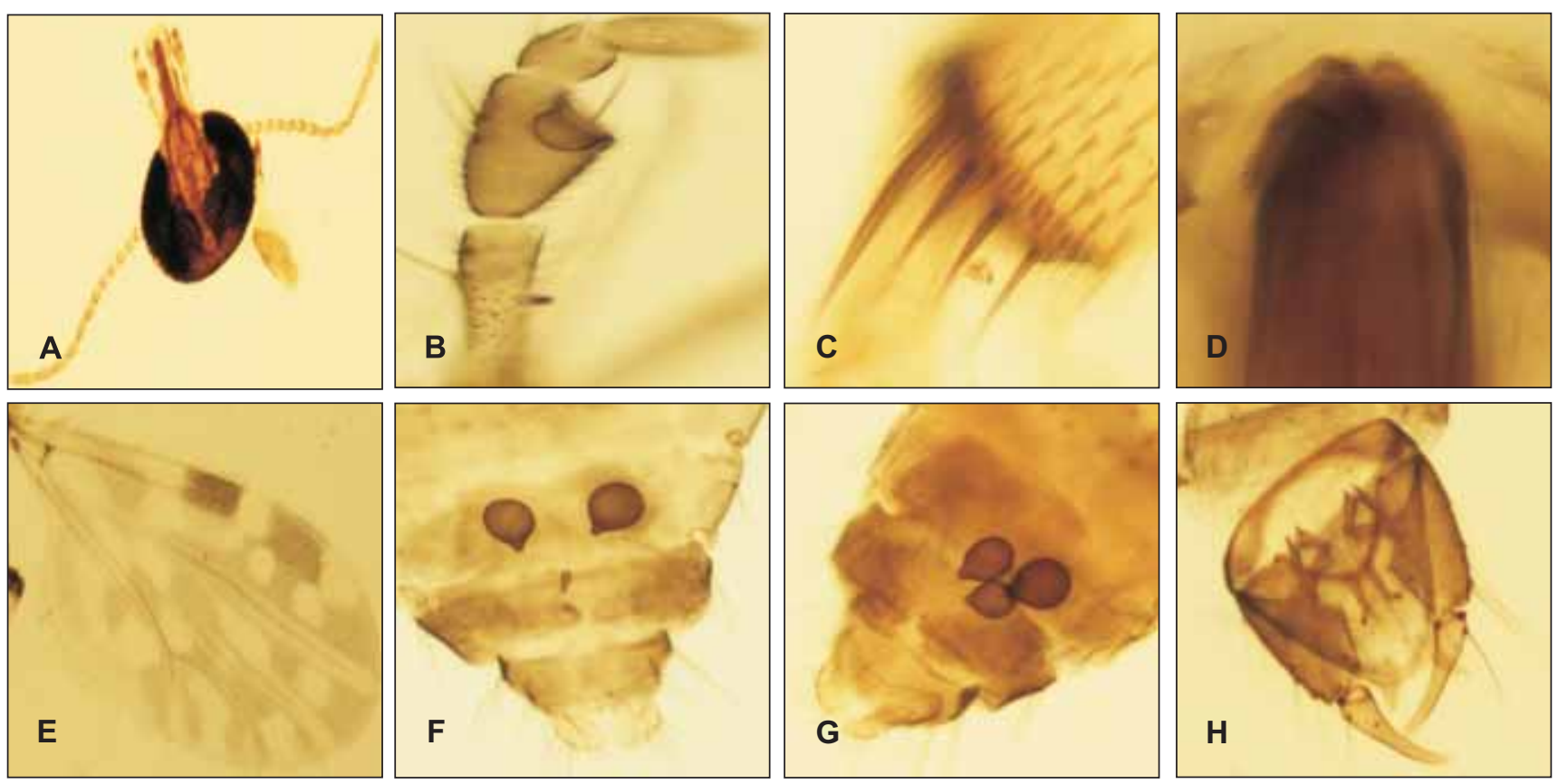

Figure-2: C. oxystoma - A. head, B. maxillary palp, C. hind tibial spine, D. mandibular teeth, E. wing F-G. spermathecae, H. male genetalia.

Other species were found in less number. C. innoxius was not found in winter season. In summer C. oxystoma was found to be highest in number followed by $\mathrm{C}$. imicola, C. actoni, C. peregrinus other species were found in less number.

\section{Discussion}

The prevalence of females were more than males in the present study which is in accordance with various authors viz Satheesha et al.[19] Reddy and Hafeez [12], Deniz et al. [20], Foxi et al. [21] and Kim et al. [22] wherein females were more than males $(75.7 \%$ $99.25 \%$ females) which may be because female flies are obligate blood feeders which are meant for egg production and oviposition. Males are not blood feeders and usually die after mating.

The prevalence of 10 different species in the present study with species composition as given in Table-1, all these species were also reported by various other authors viz Wirth and Hubert [15] from South east Asia and Dasgupta [9] from Kolkata. C. oxystoma, C. peregrinus, C. actoni, C. anophelis, C. palpifer, $C$. innoxius by Sen and Dasgupta [4] among 31 spp., which they reported from Kolkata. C. oxystoma, $C$. peregrinus, C. actoni, C. anophelis were reported by Sen and Fletcher [6] from Assam and Bengal and other parts of India among 27 spp. C. peregrinus, C. actoni by Narladkar et al. [8] from Marathwada region of 
Maharashtra. C. imicola, C. oxystoma, C. peregrinus were reported by Ganesh Udupa [10] from Tamil Nadu among $21 \mathrm{spp}$. C. actoni, C. anophelis, C. innoxius, $C$. oxystoma and $C$. peregrinus were reported by Reddy and Hafeez [12] from Chittoor and Prakasam districts of Andhra Pradesh among six spp. C. imicola, C. oxystoma by Bhoyar et al. [13] from Bidar and Mandakanahalli of Karnataka among $14 \mathrm{spp}$. C. imicola, C. oxystoma by Satheesha et al. [19] from Bidar of Karnataka among $15 \mathrm{spp}$. In all the above studies, C. imicola, C. oxystoma and $C$. peregrinus species were found to be commonly prevalent in most of the regions in India.

In the present study, C. imicola and C. oxystoma were the most predominant species which is correlated with other workers viz Ganesh Udupa [10] in Tamil Nadu, Satheesha et al. [19] in Bidar, Karnataka, and Bhoyar et al. [13] from Bidar and Mandakanahalli of Karnataka who made the same observation. Jayalakshmi [7] in Chennai and Narladkar et al. [8] in Marathwada of Maharashtra reported that C. schultzei was the most dominant spp. Reddy and Hafeez [12] reported that $C$. oxystoma was the predominant species in Chittoor and Prakasam districts of Andhra Pradesh. The variations in the occurrence of different species in different localities might be due to variations in the agro climatic and seasonal conditions in different localities/states etc [12].

In rainy season, highest number of Culicoides was found whereas it was least in summer this is in accordance with Narladkar et al. [23] who reported seasonal composition as $75.38 \%$ in rainy season, $19.75 \%$ in winter and $4.85 \%$ in summer. The above results were also found by Ilango [11] in Tamil Nadu, Reddy and Hafeez [12] in Chittoor and Prakasam districts of Andhra Pradesh, Sen and Dasgupta [4] and Dasgupta [9]. In rainy season, highest numbers of Culicoides were found whereas it was least in summer, this is because maximum temperature, low rainfall and high wind velocity deterred build-up of Culicoides and minimum temperature, high relative humidity and rainfall favoured build-up of Culicoides population significantly irrespective of species Nadlarkar et al. [23]. It can thus be concluded that rainfall plays an important influence on prevalence of Culicoides.

The seasonal prevalence of Culicoides species have been widely reported from many countries around the world. Mayo et al. [24] reported seasonal variation and impact of wastewater Lagoons as larval habitat on the population dynamics of Culicoides sonorensis at two dairy farms in Northern California. Meiswinkel et al. [25] reported seasonal fluctuations of Culicoides species in Netherlands. Diarra et al. [26] reported seasonal dynamics of Culicoides in the Niayes area of Senegal. Carvalho, L.P.C. and Silva [27] reported seasonal abundance of livestock associated Culicoides species in northeastern Brazil. Kim et al. [22] reported seasonal abundance of Culicoides in Northern Gyeonggi-do (Province), Korea. Kim et al. [28] studied the seasonal abundance of Culicoides spp. in
Republic of Korea. Ortega et al. [29] reported the seasonal abundance of biting midges, Culicoides spp. in central and southern Spain. Foxi et al. [30] reported seasonality in Sardinia (Italy). Miranda et al. [31] reported presence of midges in the Balearic Islands (Spain). Lysyk [32] studied seasonal abundance in Southern Alberta, Canada. In the present study, these species were not reported and these were different from seasons of present study. Breidenbaugh et al. [33] studied seasonal patterns of biting midges on the Parris Island Marine Corps Recruit Depot. In the present study, these species were not reported and these were different from seasons of present study. Foxi et al. [21] reported seasonal abundance of Culicoides found in northern Sardinia, Italy. The seasonal abundance patterns of the eight species of Culicoides were determined including $C$. imicola. In the present study C. imicola was found, other species did not occur, and those seasons were different from seasons of present study. Ander et al. [34] reported seasonal dynamics of biting midges in Sweden. Oem et al. [35] reported abundance of biting midge species on cattle farms in Korea. The above workers have reported seasonal abundance of Culicoides in different countries where they observed variation in the occurrence of different species in different season that were influenced by season. Therefore, season has a very important effect on prevalence of flies.

\section{Conclusion}

In rainy season, highest numbers of Culicoides were found whereas it was least in summer. In rainy season, C. oxystoma was found to be the highest followed by $C$. imicola, $C$. actoni, $C$. peregrinus whereas other species were found in less number. In winter, C. imicola was found to be highest followed by C. oxystoma, C. actoni and C. peregrinus. Other species were found in less number. $C$. innoxius was not found in winter season. In summer, C. oxystoma was found to be the highest in number followed by $\mathrm{C}$. imicola, C. actoni, C. peregrinus. Other species were found in less number.

\section{Authors' contributions}

PED designed the study, following work was carried out by MA. PED helped in species identification. CRP and SMB helped in collection of sample. All authors participated in draft and revision of the manuscript. All authors read and approved the final manuscript.

\section{Acknowledgements}

The authors acknowledge the help and cooperation of S. K. Jalali, Principal Scientist of National Bureau of Agriculturally Important Insects, Hebbal, Bangalore. The funding by the ICAR Centre of Advanced Faculty Training in Veterinary Parasitology for the research work is gratefully acknowledged.

\section{References}

1. Prasad, G. and Bhatnagar, P.K. (2000) Culicoides: Biology 
and transmission of viruses. In Acarines and Insects of Veterinary and Medical Importance. V National Training programme Centre of Advanced Studies, Department of Parasitology, Veterinary College, Bangalore, p34-38.

2. Mellor, P.S., Boorman, J. and Baylis, M. (2000) Culicoides biting midges: Their role as Arbovirus Vectors. Annu. Rev. Entomol. 45: 307-340.

3. Sen, P. and Dasgupta, S.K. (1958) Males of Culicoides anophelis. Common wealth Agricultural bureaux. p415-416.

4. Sen, P. and Dasgupta, S.K. (1959) Studies on Indian Culicoides (Diptera: Ceratopogonidae). Ann. Entomol. Soc. Am., 52: 617-630.

5. Dasgupta, S.K. (1962) Some Culicoides of Calcutta and the neighbouring areas. Sci cult. 28(11): 537-539.

6. Sen, S. K. and Fletcher, T.B. (1962) Veterinary Entomology and Acarology for India, 1st Edn. p98-120. ICAR. New Delhi.

7. Jayalakshmi.(1966) Investigation on some dipterous vectors and parasites. $\mathrm{PhD}$ thesis submitted to TANUVAS, Chennai, India.

8. Narladkar, B.W., Shastri, U.V. and Shivpuje, P.R. (1993) Studies on Culicoides spp. (Diptera: Ceratopogonidae) prevalent in Marathwada region (Maharashtra) and their host preferences. Indian Vet. J. 70: 116-118.

9. Dasgupta, S.K. (1995) Morphotaxonomic features and species of Indian Culicoides (Diptera: Ceratopogonidae). Bluetongue: Indian Perspective. Editors, Prasad, G. and Srivastava, R.N CCS HAU press, Hisar p115-188.

10. Ganesh Udupa. (2001) Culicoides spp. (Diptera: Ceratopogonidae) associated with livestock and their relevance to bluetongue infection in Tamil Nadu. $\mathrm{PhD}$ thesis submitted to Tamil Nadu Veterinary and Animal Sciences University Chennai, Tamil Nadu.

11. Ilango, K. (2006) Bluetongue virus outbreak in Tamil Nadu, southern India: Need to study the Indian biting midge vectors, Culicoides Latreille (Diptera: Ceratopogonidae). Curr Sci. 90(2): 163-167.

12. Reddy, C. V. S. and Hafeez, M. (2008) Studies on certain aspects of prevalence of Culicoides species. Indian J Anim Sci. 78 (2): 138-142.

13. Bhoyar, R., Udupa, K.G., Thimma Reddy, P.M., Madhava Prasad, C.B. and Kasaralikar, V. R. (2009) Role of climatological factors and its association with abundance of Culicoides midges (Diptera: Ceratopogonidae). Compendium XIX National Congress of Veterinary Parasitology and National symposium on "National impact of parasitic diseases on livestock health and production". Dept. of Veterinary Parasitology. College of Veterinary Sciences. Ludhiana-141004. p49.

14. Wirth W.W. and Marston, N. (1967) A method for mounting small insects on microscope slides in Canada balsam. Ann. Entomol. Soc. Am., 61: 783-78.

15. Wirth, W.W. and Hubert, A.A. (1989) The Culicoides of Southeast Asia (Diptera: ceratopogonidae) Mem. Amer. Ent.Inst. no. 44

16. Glick, J.I. (1990) Culicoides Biting Midges (Diptera: Ceratopogonidae) of Kenya.J.Med. Entomol. 27(2): 85-195.

17. Kitaoka, S. (1984) Japanese Culicoides (Diptera: Ceratopogonidae) and keys for the species I and II. Bull. Natl. Inst. Anim. Health No. 87: 73-108.

18. Pires, G.A., Ramilo, D., Diaz, S., Meireles, J., Boinas, F., Fonseca, I.P.D. (2010) Investigating morphological structures of Culicoides from obsoletus complex by using Scanning Electron Microscopy and Composed Optical Microscopy. Microscopy: Science, Technology, Applications and Education.

19. Satheesha, S. P., Udupa, K.G., Labuschagne, K and Prasanna Kumar, S. (2006) Temporal abundance of Culicoides species near the sheds of domestic animals and their possible implication on transmission of Bluetongue. National seminar on strategies for control of bluetongue. Dept. of Veterinary Microbiology. Tirupati. Andra Pradesh.
20. Deniz, A., Oncel, T. and Patakakis, M. J. (2010) Species Composition of Culicoides Latreille, 1809 (Diptera: Ceratopogonidae) in Thrace Region of Turkey. Kafkas Univ Vet Fak Derg. 16(6): 1057-1060.

21. Foxi, C., Pinna, M., Monteys, V.S.I., Delrio, G. (2011) An updated checklist of the Culicoides Latreille (Diptera: Ceratopogonidae) of Sardinia (Italy), and seasonality in proven and potential vectors for Bluetongue Virus (BTV). $P$ Entomol Soc Wash. 113(4): 403-416.

22. Kim, H.C., Bellis, G.A., Kim, M.S., Chong, S.T., Lee, D.K., Park, J.Y., Yeh, J.Y., Klein, T.A. (2012) Seasonal abundance of biting midges, Culicoides spp. (Diptera: Ceratopogonidae), collected at Cowsheds in the Southern Part of the Republic of Korea. Korean J. Parasitol. 50 (2): 127-131.

23. Narladkar, B. W., Shastri, U. V. and Shivpuje, P. R. (1993) Seasonal prevalence of Culicoides spp. (Diptera: Ceratopogonidae) in Marathwada region. Indian J Anim Sci. 63(11): 1140-1145.

24. Mayo, C.E., Osborne, C.J., Mullens, B.A., Gerry, A.C., Gardner, I.A., Reisen, W.K., Barker, C.M., MacLachlan, N.J. (2014) Seasonal variation and impact of waste-water Lagoons as larval habitat on the population dynamics of Culicoides sonorensis (Diptera: Ceratpogonidae) at two dairy farms in Northern California. Plos One. 9 (2): 1-9.

25. Meiswinkel, R., Scolamacchia, F., Dik, M., Mudde, J., Dijkstra, E., Vanderven, I.J.K., Elbers, A.R.W (2014) The Mondrian matrix: Culicoides biting midge abundance and seasonal incidence during the 2006-2008 epidemic of bluetongue in the Netherlands. Med Vet Entomol. 28: 10-20.

26. Diarra, M., Fall, M., Fall, A.G., Diop, A., Seck, M.T., Garros, C., Balenghien, T., Allène, X., Rakotoarivony, I., Lancelot, R., Mall, I., Bakhoum, M.T., Dosum, A.M., Ndao, M., Bouyer, J., Guis, H. (2014) Seasonal dynamics of Culicoides (Diptera: Ceratopogonidae) biting midges, potential vectors of African horse sickness and bluetongue viruses in the Niayes area of Senegal. Parasite Vector 7:147-158.

27. Carvalho, L.P.C. and Silva, F.S. (2014) Seasonal abundance of livestock associated Culicoides species in northeastern Brazil. Med Vet Entomol. 28(2):228-31.

28. Kim, H.C., Bellis, G.A., Kim, M.S., Klein, T.A., Chong, S.T., Park, J.Y. (2014) Seasonal abundance of Culicoides (Diptera: Ceratopogonidae) Collected by Mosquito Magnet in Northern Gyeonggi-do (Province), Korea. Korean J. Parasitol. 52(1): 57-62.

29. Ortega, M.D., Mellor. P.S., Rawlings, P. and Pro M. J. (1998) The seasonal and geographical distribution of Culicoides imicola, C. pulicaris group and C. obsoletus group biting midges in central and southern Spain. Arch Vir S. 14: 85-91.

30. Miranda, M.A., Borras, D., Rincon, C. and Alemany, A. (2003) Presence in the Balearic Islands (Spain) of the midges C. imicola and C. obsoletus group. Med Vet Entomol. 17: 52-54.

31. Lysyk, T.J. (2006) Abundance and species composition of Culicoides (Diptera: Ceratopogonidae) at cattle facilities in Southern Alberta, Canada. J. Med. Entomol. 43(5):840-849.

32. Breidenbaugh, M.S., Clark, J.W., Brodeur, R.M. and Szalay, F.A.D. (2009) Seasonal and diel patterns of biting midges (Ceratopogonidae) and mosquitoes (Culicidae) on the Parris Island Marine Corps Recruit Depot. J Vector Ecol. 34:129-140.

33. Foxi, C, and Delrio, G. (2010) Larval habitats and seasonal abundance of Culicoides biting midges found in association with sheep in northern Sardinia, Italy. Med Vet Entomol. 24: 199-209.

34. Ander, M., Meiswinkel, R. and Chiricoa, J. (2012) Seasonal dynamics of biting midges (Diptera: Ceratopogonidae: Culicoides), the potential vectors of bluetongue virus, in Sweden. Vet Parasitol. 184:59-67.

35. Oem, J. K., Chung, J. Y., Kwon, M. S., Kim, T. K., Lee, T. U. and Bae, Y. C. (2013) Abundance of biting midge species (Diptera: Ceratopogonidae, Culicoides spp.) on cattle farms in Korea. J. Vet.Sci. 14(1):91-94. 